\title{
Belgeo
}

Revue belge de géographie

\section{Electoral geography and manifestoes of new «urban» parties from 1977 to 1999: how urban are they really?}

Electorale geografie en partijprogramma's van nieuwe «stedelijke» partijen van 1977 tot 1999: hoestedelijkzijn ze echt?

Filip De Maesschalck and Maarten Loopmans

\section{OpenEdition}

\section{Journals}

\section{Electronic version}

URL: http://journals.openedition.org/belgeo/16645

DOI: 10.4000/belgeo.16645

ISSN: 2294-9135

\section{Publisher:}

National Committee of Geography of Belgium, Société Royale Belge de Géographie

\section{Printed version}

Date of publication: 30 September 2003

Number of pages: $329-342$

ISSN: $1377-2368$

\section{Electronic reference}

Filip De Maesschalck and Maarten Loopmans, "Electoral geography and manifestoes of new «urban» parties from 1977 to 1999: how urban are they really?", Belgeo [Online], 3 | 2003, Online since 30 October 2003, connection on 05 February 2021. URL: http://journals.openedition.org/belgeo/16645 ; DOI: https://doi.org/10.4000/belgeo.16645

This text was automatically generated on 5 February 2021.

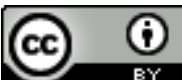

Belgeo est mis à disposition selon les termes de la licence Creative Commons Attribution 4.0 International. 


\section{Electoral geography and manifestoes of new «urban» parties from 1977 to 1999: how urban are they really?}

Electorale geografie en partijprogramma's van nieuwe «stedelijke» partijen van 1977 tot 1999: hoestedelijkzijn ze echt?

Filip De Maesschalck and Maarten Loopmans

The authors are obliged to the K.U.Leuven Department of Political Science for putting their manifesto archive at our disposal, and would like to thank Justus Uitermark (Universiteit van Amsterdam) and Christian Vandermotten (Université Libre de Bruxelles) for their valuable comments on an earlier draft of this paper.

\section{Introduction: the new urban challenge}

1 In a historical review of Belgian electoral geography Vandermotten e.a. (2001) observe that the new parties Agalev and Vlaams Blok, since their establishment at the end of the 1970s, have shown themselves increasingly as «urban» parties, to the detriment of the classical urban fractions of liberals and socialists. However, Kesteloot and De Maesschalck (2001) describe a discrepancy between the decidedly urban electorate of the Vlaams Blok and the anti-urban ideology of the party. Their Marxist interpretation of Louis Wirth's seminal definition of the urban (size, density and diversity) defines the city as a place where wealth is concentrated (size and density), wealth that can be used to liberate certain individuals of reproductive tasks to spend their time thinking, innovating, creating. They consider heterogeneity of the population and a variety of milieus as indispensable for the stimulating confrontation and exchange of ideas and information that leads to progress. The Vlaams Blok, who rejects diversity and redistribution of wealth, undermines this innovating urban milieu. According to the 
authors, Agalev is the only party that could take up the challenge of becoming a truly «urban» counterforce against this horse of Troy for the city. there exists only a small school of electoral geographers who have paid attention to what he describes as «the relation between electoral geography and the geography of party organisation and mobilisation». According to Flint (2003), this school has been firmly established within electoral geography in recent years. Influential scholars have worked on the relation between electoral geography and the local strength of party organisation (Agnew, 1996; Shin, 2001) or the relation between electoral geography and campaign spending (Forrest, 1992; 1997; Pattie and Johnston, 2003).

In this paper, we will critically assess this statement through an evaluation of both parties' party manifestoes and spatial distribution of votes throughout their first two decennia of existence, the 1980s and the 1990s.

In a first paragraph, we theoretically assess the relationship between electoral geographies, spatial electoral strategies and party manifestoes. Secondly, we draw a more detailed electoral geography of both allegedly urban parties and analyse their position in the metropolitan region. Thirdly, we relate this electoral geography to the statements concerning the city both parties make in their manifestoes. In a concluding paragraph, we will assess their value as defenders of «the urban» and evaluate the potential for a further elaboration of a geographical approach to «manifesto research».

\section{Electoral geography and manifesto research}

However, the relationship between ideological content and electoral geography remains underdeveloped. A few early studies (e.g. Johnston, 1979; Taylor and Johnston, 1979) demonstrated the relationship between geographical electoral patterns and policy propositions: In systems with majority representation, it seems that governing parties tend to pay extra attention to those districts where their majority has not been firmly established in order to win votes. These studies have been criticised later on for departing from a too simplistic and uncritical input-output logic by Taylor (1984) and Taylor and Flint (2000). Taylor claims that policy measures (output) are not simply designed to satisfy the electorate (politics of support), but aim even more to enhance capital accumulation by those capitalists who control the governmental apparatus (politics of power). Hence the input (i.e. votes) and the output (i.e. policy) can be contradictory, and input-output models do not account for that. While Taylor's «two politics» schema has put forward an important dilemma to take into account, it nonetheless proved difficult to apply in concrete research as it remains based on a highly abstract and simplified theory of the state (Reynolds, 1990).

One way to avoid the dilemma is to explicitly focus on one out of both politics. In political science, the study of politics of support has been promoted by the by now wellestablished tradition of manifesto research. Party manifestoes are the most literal and elaborated expression of party ideology accessible to the electorate (although voters will of course seldom read the whole manifesto) and explicitly serve electoral aims. Of course we must stay aware of the fact that what has been written in the manifesto will not necessarily coincide with policy measures taken afterwards. This however does not meet the argument that the politics of power will distort the electoral strategy of 
manifesto writing only to a limited extent and that an analysis of the relationship between voting patterns and manifesto content can be insightful for the analysis of the politics of support. This holds true even more for parties like Agalev and the Vlaams Blok who, for the period under scrutiny, have not been in power since their inception and hence have so far been able to focus on politics of support only.

7 The tradition of manifesto research (which has not yet received much attention in geographical circles) has been pioneered by Downs (1957). In his seminal analysis on the influence of electoral competition on party statements, he positioned parties on a left to right scale on the basis of their manifesto and analysed shifts over time. Following Downs, a school of «manifesto research» gradually developed, led by the internationally comparative Manifesto Research Group of David Robertson and Ian Budge (see Volkens, 2001 or Budge \& Bara, 2001 for a review of manifesto research). Downs' (1957) main conclusion was that in systems with majority representation, parties would inevitably soften their position, and converge to the centre.

8 Alternative hypotheses have tried to refine Down's original statement and strengthened the relationship with electoral results. Analysing party statements under different electoral circumstances, Robertson (1975) added a more dynamic approach to the original hypothesis. He assumed that parties would soften their position above all when they would not be sure of their majority and needed extra votes. When more convinced of winning the elections, they would shift more to the extremes in order to satisfy traditionally convicted voters. In time, this hypothesis has been further refined and contradicted. One counter-hypothesis (which seems to be more valuable in proportional systems) states that parties will always want to win more votes, and will always shift towards the centre.

9 The most refined hypothesis so far comes from Budge (1994), who supposes that parties always depart from a situation of complete uncertainty, and that parties are therefore relatively immobile on a left-to-right scale. Because they do not possess adequate information about the preferences of voters, they will only change their manifesto step by step, in order not to lose the votes gained at the previous elections. Previous elections proved to be the best indicators for shifting party positions. With a rising number of votes, parties hold their ground; only when the number of votes is declining, a party feels the urge for considerable manifesto changes.

10 All these models consider the complete manifesto from the point of view of a left-right scale. Robertson (1975) however, is also the inventor of the so-called «saliency theory». This theory claims that parties will always stress in their manifesto specific issues of which they can claim the "historical rights», and with which they had success in previous elections. They will try to avoid competing issues that are claimed by other parties. They will only try to reclaim other parties' issues from a different point of view, when those issues start dominating the elections. For our spatial analysis, we reinterpret Robertson's saliency theory in geographical terms: parties not only «specialise» in certain issues, but equally claim the rights on certain geographical areas in which they have a strong base. In contrast to Johnston's (1979) analysis of majority systems, we suppose that in proportional systems, parties will not so much try to emphasize districts in which the election results are unclear in order to obtain a majority, but will try to stress certain issues in their manifesto that are related to a certain socio-spatial domain in which they are strong: socio-spatial groups who are potential voters, or socio-spatial problems that a party can claim and from which 
electoral support in a certain area can be drawn (see also Duncan and Epps, 1992; Scheiner, 1999, Agnew et al., 2002). Following Budge (1994) parties will only change their ideological geography when their electoral geography is under threat. In other words, Vlaams Blok and Agalev, as allegedly «urban» parties, will stress «urban» issues in their manifesto. They will specialise on certain subjects, and will only rarely try to steal each other's issues. As long as they remain strong and growing in urban areas, they will not change their standpoints on this area and the issues connected to it.

\section{Electoral geography of Vlaams Blok and Agalev in Flanders (1977-1999)}

11 Kesteloot \& De Maesschalck (2001) demonstrated how Vlaams Blok and Agalev are markedly stronger in urban areas than in rural areas, and how this discerns both new parties from the classical ones. A detailed analysis however shows the subtle differences between both parties' electoral geography within the metropolitan area (figure 1). The results of the municipal elections (in those municipalities where the party in question did put in a list of candidates) have been classified according to the position of the municipality in the metropolitan area, following the classification of Van der Haegen et al. (1996) ${ }^{1}$. It might seem odd to analyse municipal election results together with party manifestoes for parliamentary elections. This has been a pragmatic decision, which allowed us the necessary degree of geographical refinement (municipal results of parliamentary elections are not systematically collected) to use Van der Haegen et al.'s classification. Because of the bilingual Council in the Brussels Capital Region, which complicates the analysis of electoral results, the figures are limited to Flanders 
Figure 1. Evolution of the percentage of votes for Agalev and Vlaams Blok in the different parts of the metropolitan area.

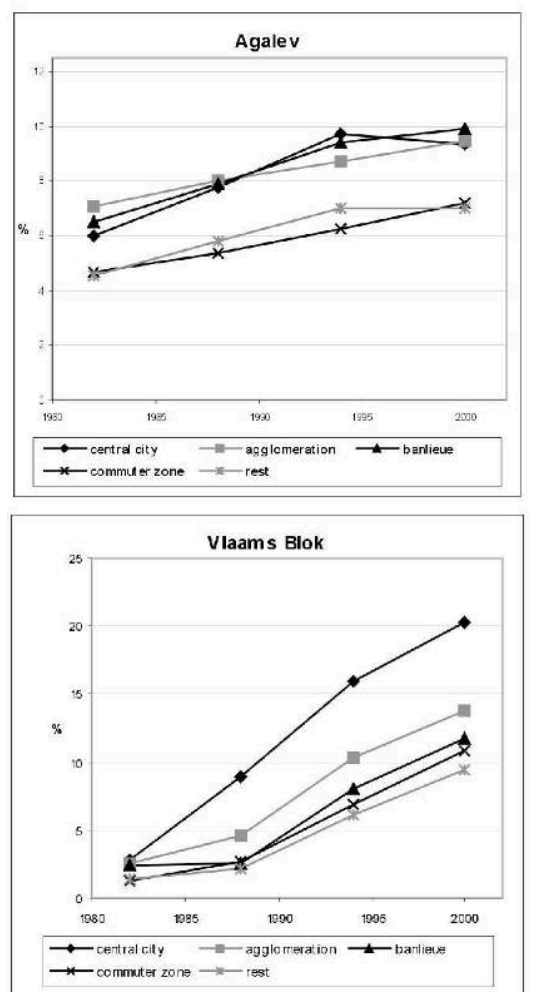

12 Figure 1 demonstrates the different spatiality of both parties. Agalev is strong in the central city, the agglomeration and the banlieue, and much weaker in the commuter zone and the rest group, mainly rural areas. The differences approximately remain the same, even though Agalev has experienced more or less continuously growing support in all zones. The Vlaams Blok is considerably stronger in the central city than in the rest of the region, and the difference increases from election to election. In electoral terms, Vlaams Blok is clearly a more urban party than Agalev, and increasingly so, even though Vlaams Blok also gains more and more support in more peripheral areas.

A second analysis, a cluster-analysis on the parliamentary elections between 1977-1999, concentrates on the electoral cantons in the metropolitan area of the two biggest Flemish cities, Antwerp and Ghent (approximated by their respective provinces of Antwerp and East-Flanders). They are analysed separately because the difference in voting outcomes between both regions is considerable. Both parties originated in Antwerp and this city is still their electoral stronghold, with markedly higher percentages than in Ghent (De Maesschalck, 2000). As opposed to the province of Antwerp, were Agalev was already present in 1977, the party made its appearance in East-Flanders only in 1981.

In both provinces, we obtained similar results with clusters forming concentric zones around the central city. The concentric zones around Antwerp (figure 2) more or less coincide with the zones of the metropolitan region. We can interpret these by means of the cluster profiles (figure 3), which show the deviation from the mean support for the respective parties in the respective years. Cluster 5 is the central city where Vlaams Blok, but also Agalev draw an important proportion of their votes. However, while the central city remains the main stronghold for the Vlaams Blok throughout the years 
(only in slight decline by the end of the period), this is not true for Agalev. Cluster 3, which coincides more or less with the agglomeration and banlieue of the city, is relatively more important for Agalev and less so for Vlaams Blok. Throughout the years, this zone slightly increases its importance for the Vlaams Blok, and slightly decreases for Agalev. Cluster 2 overlaps to a large extent with the banlieue and commuter zone. Vlaams Blok does not draw much support here but this zone gains in importance for Agalev, what seems to be related to proceeding suburbanisation. Cluster 1 is a more rural area, where both parties are relatively weak. In the south of the province, the pattern is disturbed by the industrial region Boom-Puurs-Mechelen, waar Vlaams Blok is relatively strong, but not Agalev. As said, we obtained a similar pattern with the cluster-analysis for East-Flanders (figure 4), although the concentric pattern is more disturbed by regional anomalies; the city of Ghent is considerably smaller than Antwerp and its area of influence does not cover the whole of the province. Hence cluster 3 does not only cover the Ghent inner city and part of its agglomeration (of which the major part is located within the administrative borders of the city of Ghent), but also includes the western extension of the Antwerp metropolitan area into the province of East-Flanders. Cluster 4 is comparable to cluster 2 in the case of Antwerp and cluster 1 is similar to the Antwerp cluster 1. Cluster 2 and 5 show specific patterns that have to do with the influence of Brussels and the early industrialized character of the area. Nonetheless, both analyses confirm the results of the previous one on municipal elections: all three show a more or less stable pattern throughout the years where Vlaams Blok voters are strongly concentrated in the central city, while Agalev voters are more spread out over central city, agglomeration and banlieue. In electoral terms, Vlaams Blok is clearly the most «urban» party, while Agalev is «urban» and «suburban» at the same time. In the following analysis of both parties' manifestoes, we will assess how this works through in their ideology.

Figure 2. Results of the cluster-analysis on the election results of Agalev and Vlaams Blok in the province of Antwerp from 1977 to 1999.

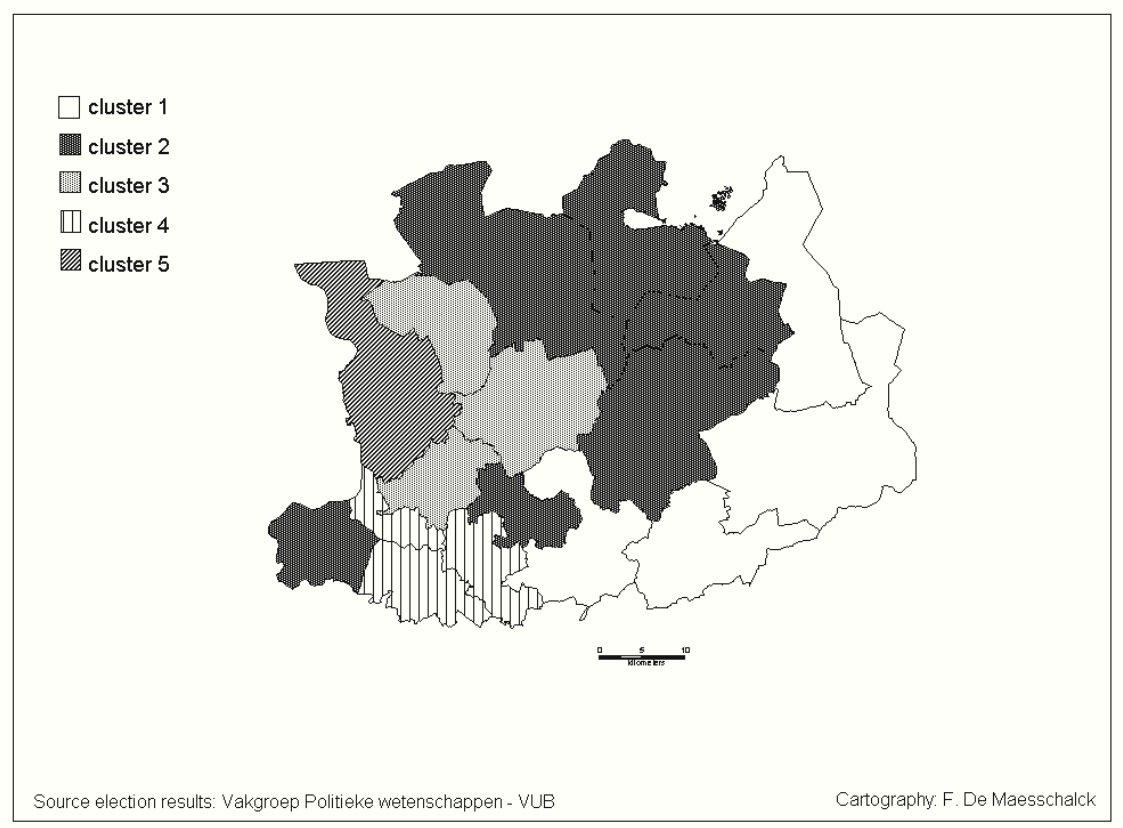


Figure 3. Cluster profiles for the province of Antwerp.
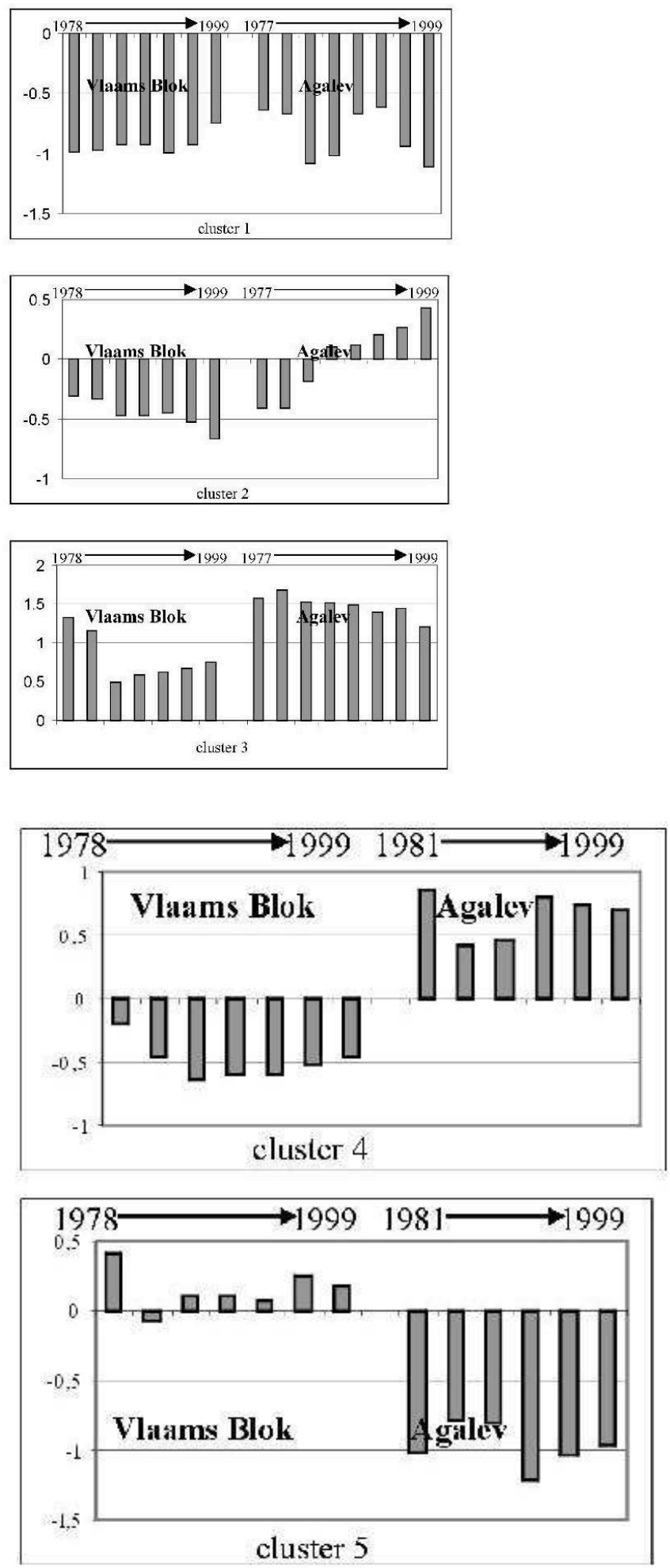
Figure 4. Results of the cluster-analysis on the election results of Agalev and Vlaams Blok in the province of East-Flanders from 1977 to 1999.

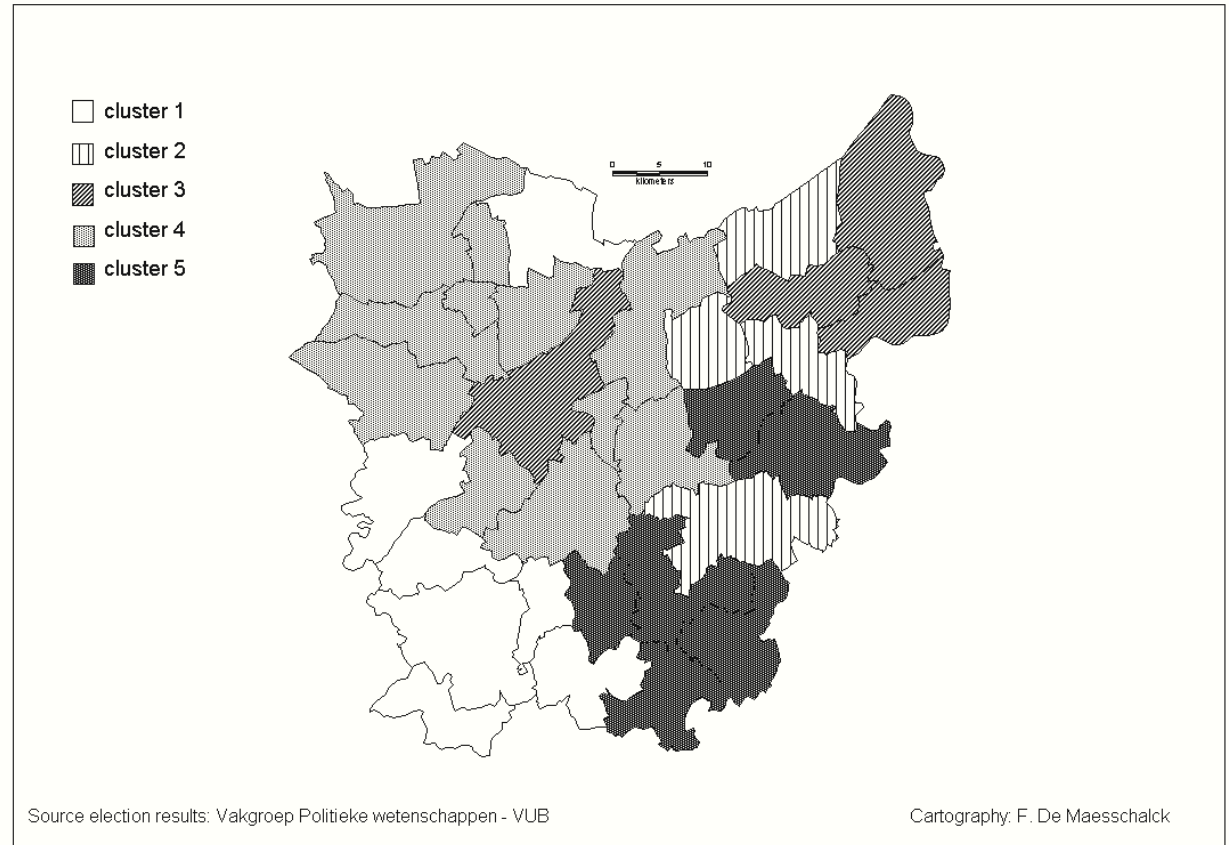

\section{The party manifestoes of Vlaams Blok and Agalev}

Classical manifesto analysis makes use of rather sophisticated quantitative methods of media-analysis to construct left-right scales. For the sake of this explorative analysis, we limited ourselves to a more qualitative approach. What is important for us is to give an overview of the appearance of urban issues in both parties' manifestoes in the two decennia under scrutiny. What is striking is that none of the two parties actually drops issues or standpoints in subsequent manifestoes once they have been taken. This might mean that the issues mentioned do indeed form part of the parties «hometurf». In the following overview, we will not mention every standpoint each year, but only point to the year of appearance, or the year it underwent considerable changes.

\section{Vlaams Blok}

From 1978 until the late 1980s, the Vlaams blok manifesto was more of a pamphlet of a few sheets long. In their original manifestoes, the party did not yet pay much attention to urban problems. The emphasis was on Flemish independence, European unification (as a defence against Soviet and Anglo-American imperialism) and a reform of the economy towards a corporatist model. «Guest labourers», as labour migrants were still called in their publications, did not get much attention; their forced repatriation was demanded for the sake of cultural homogeneity and to protect them from becoming uprooted.

However, 1985 is a turning point. The «guest labourers' problem» comes more to the fore, and for the first time, the connection between immigrants and cities is made. Under the heading «Birmingham», a paragraph is devoted to the appearance of 
ghettoes and the manifesto implicitly connects this to the racial riots in Handsworth, Birmingham that were seen on television:

«The presence of a great number of guest labourers in a limited number of confined spaces (mostly in certain neighbourhoods in big cities) will create ever growing and more terrifying problems. (...) The Vlaams Blok repudiates the 'Brazilification' of Flanders. Lest the images of Birmingham take place in Flanders.» (translation by authors)

In 1987, everyday «insecurity» makes its first explicit appearance in the Vlaams Blok manifesto.

«We are worried about increasing insecurity on the street, in the shop and often even at home. Crime is increasing. In ever more neighbourhoods of our big and medium-sized cities it is not advisable to venture oneself out in the dark.» (translation by authors)

Yet the presence of immigrants is not yet explicitly linked to it. Still, the "guest labourers' problem» is one of uprootedness and redundancy; there is no work for them anymore. Like in their first manifestoes, the solution «work in your own region» is still the essence of the Vlaams Blok repatriation policy.

In 1991, the Vlaams Blok eventually does put the blame for insecurity (in cities) on immigrants:

«Masses of Turks, Moroccans, etc. are stick together in our big cities. Second and third generation youngsters are uprooted and form an enduring focus of dissatisfaction and crime.» (translation by authors)

The Vlaams Blok likes to cheer up its analysis with police data:

«A recent state police report proves that crime-rates among non-European foreigners are four times higher than among the own population. 1 on 3 (33\%) of the imprisoned criminals are foreign...» (translation by authors)

With the explicit link between foreigners-crime-insecurity in big cities, the Vlaams Blok has found its hit story. The elections of 24 November 1991 are the first to be called «Black Sunday». Vlaams Blok raises its votes from $3 \%$ to $10.3 \%$ in Flanders. Year after year, the Vlaams Blok will repeat its story on what they call «the three V's: Vlaanderen, vreemdelingen, veiligheid». (Flanders, foreigners, security). In 1995, the Vlaams Blok rises from 10.3 to 12.2 , in 1999 from 12.2 to 15.3 . Increasingly, the party stresses the link between the last two V's: foreigners and security. In 1999, the last manifesto we analysed, the chapters on foreigners and insecurity (in which many explicit links to foreigners appear) occupy 31 of the 140 pages manifesto. Moreover, the same issues reappear regularly under other headings: e.g. under the heading "poverty» («the Vlaams Blok thinks that many projects of the Social Impulse Fund (SIF) ${ }^{2}$, who took over the budget of the Flemish Fund for the Integration of Deprived Persons (VFIK), have often been misused to oversubsidize projects for foreigners») or under «Elderly policy» («a safe living environment for elderly»).

\section{Agalev}

Agalev's first manifesto appears only in 1981. Like the first Vlaams Blok manifestoes, it is not much more than a pamphlet and only contains one standpoint on urban policy or urban issues. In a reaction to the urban renewal of the 1970s, limited to a physical renewal of derelict housing blocs, Agalev stresses the need to increase the "liveability» of neighbourhoods by better facilities and services. An important advantage of such a 
«social renewal» would be to reduce suburbanisation and the (energy wasting, polluting) commuting that it brings along.

Suburbanisation or «urban flight», as it is called in Agalev manifestoes, will stay central to any urban policy measure Agalev further proposes. In 1985, the issue of urban renewal is elaborated further. Again the inner city, depicted as an insalubrious and unhealthy environment of «derelict neighbourhoods in which only the poorest stay behind», has to be made liveable again, by a policy of social urban renewal, renovation and compact urbanisation. This is necessary to counter the building up of open spaces and increasing pollution brought about by suburbanisation and commuting.

New «urban» standpoints are also added to the manifesto: Agalev wants a reorientation of housing policy, now aiming too much on private building and owneroccupation; which again has led to uncontrolled suburbanisation.

Yet Agalev is not solely preoccupied by the protection of open spaces and the countryside against suburbanisation. In its 1985 manifesto, the party also expresses its worries about poverty that is explained by a failing housing policy and the «arbitrariness of the private rental market».

«The Green strife for an equitable distribution of the available living space and

living expenses, the preservation and renovation of existing houses (e.g. by urban

renewal).» (translation by authors)

According to Agalev, social housing construction has to be intensified, in order to provide decent housing with minimum comfort to all. The private rental market has to be controlled more strictly, to the advantage of the tenant. Social displacement has to be countered and renovation has to be made possible for the lower income groups by means of rent subsidies.

In 1985, Agalev also has an eye for immigrants: the concentration of immigrants in isolated, deprived neighbourhoods preserves existing prejudices about them; it is therefore necessary to pay attention to decent housing for foreigners.

The manifesto of 1987 is an almost perfect copy of the 1985 one, although this is the first year Agalev says something about asylum seekers: they should be spread over the country, to raise country-wide consciousness of the problems in the third world.

In 1991, the content of the manifesto does not change much either. Agalev now works with a general manifesto and thematic pamphlets, of which the general manifesto is a summary. In the manifesto, little is said about housing, and urban renewal is again reduced to an action against «urban flight». Agalev does however pay some attention to "the poorest families» and «the original inhabitants», by claiming an adaptation of the housing law. The pamphlet on social policy puts more emphasis on housing; Agalev demands attention for the housing problems of the poorest. They emphasize the problems of access to social housing, but also stress that the integration of social housing projects in the urban tissue and the provision of a diversity of houses should prevent them from becoming ghettoes.

31 In 1995, Agalev pays more attention to the city again. Apart from the reappearing older claims, they now demand a «Fund for Urban Renewal» to counter the worst housing problems and decay, a long-range plan for social housing and small-scale renewal actions in the living environment, and an active land acquirement policy.

What is more significant however is that the 1995 manifesto also witnesses the appearance of an urban theme that so far had been totally absent of Agalev's ideology. 
After the Vlaams Blok's spectacular success in 1991, Agalev equally seems to feel the need to address the issue of insecurity. Agalev's explanation and solution of insecurity however stand in sharp contrast to what Vlaams Blok has to say about this; for the Green, feelings of insecurity are a consequence of individualisation and poverty, rather than of an increase in crime. Therefore crime has to be addressed with soft prevention rather than repression. Repression should be preserved for capital offences, environmental crimes and assaults on public health, fiscal fraude, corruption, drug maffia, trading humans, rather than for petty crime.

In 1999 insecurity is elaborated further, similarly stressing capital, environmental and white-collar crime, but with increasing attention to «violent crimes in general and every act that stimulates feelings of insecurity». Repression is no longer a taboo, and Agalev offers some concrete suggestions, while at the same time demanding attention for what they call "social safety». Physical interventions in the urban environment have to be "socially safe», trams should again have their good old conductors, who might even have limited police authority. The SIF is called a valuable instrument for welfare and redistribution. However, an increased liveability of the city remains in the first place a means to counter suburbanisation and Agalev demands a «Fund for Urban Renewal» next to the SIF.

\section{Conclusion}

Both Agalev and Vlaams Blok are alleged to be distinctively «urban» parties. Nonetheless, a detailed analysis of the history of their electoral geography in their first two decennia of existence shows clearly different patterns. Vlaams Blok is indeed strongly embedded in the inner city. Even while since 1995 the party increasingly draws support from the agglomeration, the gap with the inner city is far from being filled. Agalev on the contrary, is strong in the inner city, as well as in the agglomeration and banlieue, and this since its most early days.

This subtle difference is clearly reflected in both parties' ideologies as translated in their manifestoes. Both parties pay considerable attention to issues related to their electoral strongholds. Throughout the years, Vlaams Blok has focused increasingly on explicitly urban issues and clearly owes a great deal of its succes to it. Agalev on the other hand always had to satisfy a suburban, as well as an urban electorate, and has throughout the whole period tried to balance the demands of both. In line with classical manifesto research, we can here suppose a dialectical relationship between electoral competition and manifesto content; what is new is that this relationship also seems to have a spatial element. The spatial references in the manifesto stayed remarkably the same throughout the more than 20 years under scrutiny, giving support to the thesis of Budge on the relative ideological immobility of parties.

In line with Robertson's saliency theory, Agalev, nor Vlaams Blok try to cover the whole range of urban issues, but have carved out neatly separated niches. Agalev does not pay much attention to insecurity, and when the issue of immigrants is taken up, this is a reaction to «racism and prejudices». Vlaams Blok is not interested in town and country planning or urban renewal, let alone suburbanisation. Only once, after the Vlaams Blok's spectacular success in 1991, where insecurity seemed to have been the "talk of the town", Agalev felt the urge to consider this typical Vlaams Blok issue. They nonetheless tried to approach it from a completely different, more «leftist» angle- only 
to shift more to the centre after another electoral success of the Vlaams Blok in 1995 on the base of the same topic.

In the light of these results, it is doubtful that Agalev would be capable to become a «leftist» challenger to the urban success of the Vlaams Blok. Contrary to the latter, Agalev is forced to satisfy two different socio-spatial milieus, and will not be able to choose for the city at full length. In their manifesto, urban measures such as urban renewal simultaneously serve suburban goals, such as the preservation of open space or the limitation of commuter traffic. When forced to choose, urban and suburban demands are in fierce competition, as has been demonstrated when Agalev dropped the demand of suffrage for immigrants when coming to power in 1999, in favour of more suburban demands (see Kesteloot, 1999). The Vlaams Blok does focus rather exclusively on urban issues, but departs from a particularly dystopian view of the city and indeed proposes an inherently anti-urban strategy of repression and rejection of urban diversity.

The theoretical value of this analysis lies in the fact that it has shown the importance of a spatial analysis of party strategies of support. Putting forward spatially related issues in their ideology, parties do indeed draw support from geographically specific electorates. Consciously or subconsciously, parties seem to take electoral geography into account in their strategies of support, such as manifesto writing. The classical manifesto analyses so far have given prominence to the analysis of cleavages within an essentially national electorate. This analysis however shows how party ideologies equally reflect spatial differentiations or cleavages within the national electorate. For a full understanding of politics of support, political scientists cannot ignore these spatial strategies.

Political geographers have so far ignored the importance of manifesto research. Nonetheless, the electoral geography of parties can be better explained if we take into account the spatial elements of their ideology. As Savage (1987) puts it, voting behaviour is mediated by materially significant aspects of place. At least some parties seem to make use of these spatially differentiating elements to carve out an electoral niche that provides them with a more or less stable base of support.(A geographical interpretation of) manifesto research allows us for instance to endeavour making some predictions after the very interesting Belgian parliamentary elections of May 2003. In previous elections, Agalev nor Vlaams Blok were inclined to change their manifesto drastically, because both showed a rather stable growth path. However in 2003, Agalev experienced a drastic loss of votes. This might force the party to relatively important ideological innovation; indeed, the party claims to have started this process. At the same time, the Vlaams Blok seems to have finally broken through in more peripheral zones of the metropolitan area and might feel obliged to pay more attention to nonurban issues. The transformation of the socialist party from a decidedly urban into a more peripheral party - simultaneous with and under the pressure of the urban advent of both Agalev and Vlaams Blok - might prove an interesting case to look at as an example for these future developments. 


\section{BIBLIOGRAPHY}

AGNEW J. (1990), «From political methodology to geographical social theory? A critical review of electoral geography, 1960-87», in JOHNSTON R.J., SHELLEY F.M. \& TAYLOR P.J., Developments in Electoral Geography, London, Routledge.

AGNEW J. (1996), «Mapping politics: How context counts in electoral geography», Political Geography, 15, 2, pp. 129-146.

AGNEW J., SHIN M. \& BETTONI G. (2002), «City versus metropolis: the Northern League in the Milan Metropolitan Area», International Journal of Urban and Regional Research, 26, 2, pp. 266-283.

BUDGE I. (1994), «A new spatial theory of party competition: uncertainty, ideology and policy equilibria viewed comparatively and temporally», British Journal of Political Science, 24, 4, pp. 443-467.

BUDGE I. \& BARA J. (2001), «Manifesto-based research: a critical review», in BUDGE I., KLINGEMANN H., VOLKENS A., BARA J. \& TANENBAUM E. (eds.), Mapping policy preferences, Oxford, Oxford University Press.

DE MAESSCHALCK F. (2000), «Electorale geografie van het Vlaams Blok. De ruimtelijke evolutie van de verkiezingsuitslagen van 1981 tot en met 1995», De Aardrijkskunde, 24, 1-2, pp. 21-36.

DOWNS A. (1957), An economic theory of democracy, New York, Harper.

DUNCAN C. \& EPPS W. (1992), «The demise of 'countrymindedness': New players or changing values in Australian rural politics», Political Geography, 11, 5, pp. 430-448.

JOHNSTON R.J. (1979), Political, electoral, and spatial systems: an essay in political geography, Oxford, clarendon.

FLINT C. (2003), «Political geography II: terrorism, modernity, governance and governmentality», Progress in Human Geography, 27, 1, pp. 97-106.

FORREST J. (1992), «The geography of campaign funding, campaign spending and voting at the New-South-Wales legislative assembly elections of 1984», Australian Geographer, 23, 1, pp. 66-76.

FORREST J. (1997), «The effects of local campaign spending on the geography of the flow-of-thevote at the $1991 \mathrm{New}$ South Wales state election», Australian Geographer, 28, 2, pp. 229-240.

KESTELOOT C. (1999), «Stedelijkheid in Vlaanderen: een nieuwe politieke inzet», Vlaams Marxistisch Tijdschrift, 33, 4, pp. 18-30.

KESTELOOT C. \& DE MAESSCHALCK F. (2001), «Anti-urbanism in Flanders: the political and social consequences of a spatial class struggle strategy», Belgeo, 2, 1-2, pp. 41-62.

PATTIE C.J. \& JOHNSTON R.J. (2003), «Local battles in a national landslide: constituency campaigning at the 2001 British General Election», Political Geography, 22, 4, pp. 381-414. REYNOLDS D. (1990), «Whither electoral geography? A critique», in JOHNSTON R., SHELLEY F. \& TAYLOR P. (eds.), Developments in electoral geography, London, Routledge.

ROBERTSON D. (1976), A theory of party competition, London, Wiley.

SAVAGE M. (1987), «Understanding political alignments in contemporary Britain: do localities matter?» Political Geography Quarterly, 6, pp. 53-76. 
SCHEINER E. (1999), «Urban outfitters: city-based strategies and success in post-war Japanese politics», Electoral Studies, 18, 2, pp. 179-198.

SHIN M. (2001), «The politicisation of place in Italy», Political Geography, 20, 3, pp. 331-352.

TAYLOR P.J. and JOHNSTON R.J. (1979), Geography of elections, London, Croom Helm.

TAYLOR P.J. (1984), «Accumulation, legitimation and the electoral geographies within liberal democracy», in TAYLOR P. \& HOUSE J. (eds.), Political geography: recent advances and future directions, London: Croom Helm.

TAYLOR P.J. \& FLINT C. (2000), Political geography. world economy, nation-state and locality, Harlow, Pearson Education Limited.

VAN DER HAEGEN H., VAN HECKE E. \& JUCHTMANS G. (1996), «De Belgische stadsgewesten 1991», Statistische studiën, 104.

VANDERMOTTEN C., DECROLY J.-M., DESSOUROUX C. \& ROUYET Y. (2001), «Permanences et ruptures dans la géographie électorale de la Belgique», Belgeo, 2, 1-2, pp. 7-39.

VOLKENS A. (2001), «Manifesto research since 1979», in LAVER M. (ed.), Estimating the policy position of political actors, London, Routledge.

\section{NOTES}

1. We considered each zone of the metropolitan area (central city, agglomeration, banlieue, commuter zone, rest) to be a sociological unity. Therefore we did not count the average of the percentages per party of each commune in a certain zone, but took the percentage per party of all the votes in a certain zone.

2. The Flemish «Social Impulse Fund» or SIF was the main instrument of the first explicit urban policy in Belgium. One of the explicit aims of the Flemish government when appointing socialist Leo Peeters «minister of urban policy» was to counter the electoral success of the Vlaams Blok by enhancing the liveability of the urban environment and the fight against (urban) poverty.

\section{ABSTRACTS}

This paper examines the relationship between electoral results and party manifestoes from a spatial perspective. The manifestoes and electoral geography of two new, allegedly «urban» parties in Flanders are compared in order to assess whether these parties might, in their ideas and consequential policies, contribute to a reinforcement of the urban milieu in Flanders. We end up with a rather pessimistic conclusion: the Vlaams Blok, adhering an inherently anti-urban ideology, nor Agalev, who have to satisfy a suburban as well as an urban electorate, seem to be able to defend the urban milieu in Flanders.

In dit artikel wordt de relatie tussen electorale resultaten en partijprogramma's onderzocht vanuit een ruimtelijk perspectief. De partijprogramma's en de electorale geografie van twee schijnbaar «stedelijke» partijen in Vlaanderen worden vergeleken om na te gaan of deze partijen, in hun ideeën en daaruit volgend beleid, bijdragen aan een versterking van het stedelijke milieu 
in Vlaanderen. We besluiten met een eerder pessimistische conclusie: noch het Vlaams Blok, dat een inherent anti-stedelijke ideologie aanhangt, noch Agalev, die rekening moet houden met een stedelijk zowel als een suburbaan electoraat, lijken in staat te zijn de belangen van het stedelijke milieu te verdedigen.

INDEX

Keywords: party manifesto, electoral geography, urban party, Vlaams Blok, Agalev Trefwoorden partijprogramma, electorale geografie, stedelijke partij, Vlaams Blok, Agalev

\section{AUTHORS}

\section{FILIP DE MAESSCHALCK}

Institute for Social and Economic Geography, Catholic University of Louvain, Filip.DeMaesschalck@geo.kuleuven.ac.be

\section{MAARTEN LOOPMANS}

Aspirant FWO-Vlaanderen, Institute for Social and Economic Geography, Catholic University of Louvain, Maarten.Loopmans@geo.kuleuven.ac.be 